\title{
Construction and validation of an educational video for human papillomavirus vaccination
}

\author{
Construção e validação de vídeo educacional para vacinação contra o papilomavírus humano
}

Construcción y validación de vídeo educativo para la vacunación contra el virus del papiloma humano

Iris Nayara da Conceição Souza Interaminense'
ORCID: 0000-0002-0630-7703

Sheyla Costa de Oliveira'

ORCID: 0000-0003-0485-1729

Francisca Márcia Pereira Linhares'

ORCID: 0000-0001-9778-5024

Tatiane Gomes Guedes'

ORCID: 0000-0001-7149-2290

Vânia Pinheiro Ramos' ORCID: 0000-0002-4559-934X

Cleide Maria Pontes' ORCID: 0000-0003-4707-6873

'Universidade Federal de Pernambuco. Recife. Pernambuco, Brazil.

How to cite this article: Interaminense INCS, Oliveira SC, Linhares FMP, Guedes TG, Ramos VP, Pontes CM. Construction and validation of an educational video for human papillomavirus vaccination.

Rev Bras Enferm. 2020;73(4):e20180900. doi: http://dx.doi.org/10.1590/0034-7167-2018-0900

Corresponding author: Iris Nayara da Conceição Souza Interaminense E-mail: irisnarea@yahoo.com.br

EDITOR IN CHIEF: Antonio José de Almeida Filho ASSOCIATE EDITOR: Hugo Fernandes

Submission: 03-18-2019

Approval: 07-04-2019

\begin{abstract}
Objectives: to validate an educational video aimed at the adhesion of human papillomavirus vaccination. Methods: a methodological study, where the knowledge about the theme and the technology to be constructed in six focal groups was identified; a theoretical framework was set up and the existing videos were uploaded. After that, pre-production, production and post-production were followed. In validation of content, 22 specialists participated, and in appearance, ten adolescents, ten mothers, ten teachers and ten audiovisual professionals. Absolute frequency, Binomial Test, and Content Validity Index were used. Results: agreement was satisfactory in most items. Regarding relevance, 20 items had indices above 0.80 among judges. Assessment was positive among girls and mothers. Only three items had indices less than 0.80 among teachers and video professionals. Conclusions: the educational video was validated, conferring credibility to contribute to educational actions and improve vaccination indexes.
\end{abstract}

Descriptors: Construction; Validation Studies; Video-Audio Media; Vaccination; Papillomaviridae

\section{RESUMO}

Objetivos: validar um vídeo educacional direcionado à adesão da vacinação contra o papilomavírus humano. Métodos: estudo metodológico, em que se identificou o conhecimento sobre a temática e a tecnologia a ser construída em seis grupos focais; organizou-se um referencial teórico e levantou-se os vídeos existentes. Após, seguiram-se os estágios de préprodução, produção e pós-produção. Na validação de conteúdo, participaram 22 especialistas e, na de aparência, dez adolescentes, dez mães, dez professores e dez profissionais da área de audiovisuais. Calculou-se frequência absoluta, Teste Binomial e Content Validity Index. Resultados: a concordância foi satisfatória na maioria dos itens. Quanto à relevância, 20 itens tiveram índices acima de 0,80 entre os juízes. A avaliação foi positiva entre meninas e mães. Apenas três itens apresentaram índices menores que 0,80 entre os professores e profissionais de vídeo. Conclusões: o vídeo educacional foi validado, conferindo credibilidade para contribuir nas ações educativas e melhorar os índices vacinais.

Descritores: Construção; Estudos de Validação; Mídia Audiovisual;Vacinação; Papillomaviridae.

\section{RESUMEN}

Objetivos: validar un vídeo educativo dirigido a la adhesión de la vacunación contra el papilomavirus humano. Métodos: estudio metodológico, donde se identificó el conocimiento sobre la temática y la tecnología a ser construida en seis grupos focales; se organizó un referencial teórico y se levantaron los videos existentes. Después, se siguieron las etapas de pre-producción, producción y post-producción. En la validación de contenido, participaron 22 especialistas y, en la de aparición, diez adolescentes, diez madres, diez profesores y diez profesionales del área de audiovisuales. Se calculó la frecuencia absoluta, Prueba Binomial y Content Validity Index. Resultados: la concordancia fue satisfactoria en la mayoría de los ítems. En cuanto a la relevancia, 20 ítems tuvieron índices por encima de 0,80 entre los jueces. La evaluación fue positiva entre las niñas y las madres. Sólo tres ítems presentaron índices menores que 0,80 entre los profesores y profesionales de vídeo. Conclusiones: el video educativo fue validado, otorgando credibilidad para contribuir en las acciones educativas y mejorar los índices vacunales.

Descriptores: Construcción; Estudios de Validación; Medios Audiovisuales; Vacunación; Papillomaviridae. 


\section{INTRODUCTION}

The quadrivalent human papillomavirus (HPV) vaccine was introduced in the Brazilian Unified Health System (SUS Sistema Único de Saúde) in 2014 as a strategy for the prevention of cervical cancer, which has a high incidence and mortality, including in developing countries. The production of this vaccine is associated with virus infection, with subtypes 16 and 18 accounting for about $70 \%$ of the cases of neoplasm. This and other evidence on immunobiology are poorly understood and interfere with its acceptability ${ }^{(1-2)}$, although approval for use in women occurred in 2006 and in humans in 2009, attesting to safety in administration ${ }^{(3)}$.

In Brazil, the Ministry of Health (MoH) currently determines that the target population for vaccination is girls aged 9 to 14 and boys aged 11 to 14 years. By 2020, the age range of immunization in the male population is expected to increase from nine to 14 years $^{(4)}$. Since vaccine became available in the public health network, concerns arose in families about early sexual life of the young and fear of adverse events after immunization. The information disclosed in the media and social networks are another aggravating factor that can impair adherence and, consequently, failure to comply with the vaccination schedule, leading to a decrease in immunization rates ${ }^{(1)}$.

In 2014, HPV vaccination rates in Brazil were approximately $99.8 \%$ and $55.7 \%$ for the first and second doses, respectively, when the vaccine was offered to girls aged 11 to 13 years ${ }^{(5)}$. By 2017 , vaccine coverage in girls was $82.6 \%$ and $52.8 \%$, respectively for the first and second doses, and $43.8 \%$ for the first dose in boys ${ }^{(1)}$. These results demonstrate a significant reduction in vaccine administration, weakening the fight against cancer.

Encouraging vaccination, through educational actions, is necessary in this setting, making the knowledge about the subject accessible and sensitizing different publics, especially in schools, that needs practices that promote quality of life. To this end, it is recommended to use modern technologies such as videos ${ }^{(1)}$. It stands out for the ease of access and ability to streamline didactic-pedagogic activities, constituting a resource that enhances learning, such as educational video. However, many videos available do not present persuasive communication, a strategy useful for generating healthy behaviors ${ }^{(6)}$.

The development of an educational tool with the participation of the target public of vaccination, parents and health and education professionals gives the material credibility to contribute to health education actions and, thus, improve the vaccination indexes, which are currently below expected. This development is based on official information about immunobiological and reliable references submitted to the validation by specialists and other actors involved with immunization and video production, that can boost thinking for the change of attitudes and behavior.

\section{OBJECTIVES}

To validate an educational video aimed at the adhesion of human papillomavirus vaccination.

\section{METHODS}

\section{Ethical aspects}

The study was approved by the Research Ethics Committee of the Health Sciences Center of the Universidade Federal de Pernambuco, through submission to the Brazil Platform (Plataforma Brasil). It followed the recommendations of Resolution 466/12 of the Brazilian National Health Board (Conselho Nacional de Saúde).

\section{Design, place of study and period}

The study is of the methodological type, which develops, validates and assesses tools and research methods ${ }^{(7)}$. As no specific tools were found to guide this methodology, it was decided to follow a sequence of procedures based on the literature, namely: construction of the initial version of the educational video(8), validation of content $\mathrm{t}^{(9)}$ and validation of appearance ${ }^{(9)}$.

In the first stage, diagnosis of knowledge and attitudes about HPV and vaccination was made, and the educational tool was chosen through six focus groups from June to July 2015. The operationalization of these groups occurred in elementary schools, municipal and state, and health units located in Health District IV of the city of Recife, Pernambuco State, defined by lottery. In the group of higher-level health professionals, the activity was developed during the District's administrative meeting.

Validation of content occurred in November and December 2015, while the validation of appearance, carried out in the municipal public schools and state elementary schools of the same District, occurred in December 2015.

\section{Population or sample, inclusion and exclusion criteria}

Focus groups were constituted of six students, ten adolescents, nine mothers, ten teachers, seven Community Health Agents (CHA) and 13 higher level health professionals ${ }^{(10)}$ selected by intentional sampling ${ }^{(7)}$.

As inclusion criteria for participation in the groups, students should be in the age range of vaccination, which corresponds to the series from the fourth to the eighth year. Those who were excluded from school activities due to illness or suspension were excluded. The invitation to participate in the study was made to the parents, but only the mothers were available to attend the meeting. It was necessary to have daughters with the described profile, being excluded those that had some cognitive limitation. Teachers should teach in the mentioned series and health professionals work in local health units.

In the validation of content stage, 22 professionals $s^{(11)}$ participated in the areas of women's and/or adolescent's health, public health, collective health and health education, teaching or assistance, with at least five years of practice. The selection followed the inclusion criteria based on the experiment classification system adapted from the Fehring model ${ }^{(12)}$, considering a specialist with at least five points. The active search of the same occurred in the Lattes Platform (Plataforma Lattes), being the sampling of the intentional type $\mathrm{e}^{(7)}$. 
Validation of appearance was performed with ten adolescents, ten mothers and ten teachers ${ }^{(13)}$ selected by the same criteria used in the focus groups. Only mothers were available. Ten professionals from the video area ${ }^{(13)}$, with experience in production and publication participated, and were selected by chain sampling ${ }^{(7)}$.

\section{Study protocol}

In the development of the focus groups, a script was developed with five guiding questions, adapted according to the participating public, on HPV, immunization and educational materials, using the problematizing methodology. They had an average duration of 37 minutes. From the transcription of the audios and exhaustive reading of the texts, the knowledge and attitudes about the subject and the video as the chosen educational technology were identified.

Subsequently, a video survey was conducted and a theoretical framework was made on HPV and vaccination. There were also verified productions with the theme in the collections of the Oswaldo Cruz Foundation (Fundação Oswaldo Cruz), MoH, State Health Offices of Brazil and Federal District, to make a video different from those previously published, being located 22 audiovisual materials. All of these steps contributed to the video's script.

The educational video production process was organized in three stages: pre-production, production and post-production ${ }^{(8)}$. In pre-production, the idea was defined, followed by script writing ${ }^{(14)}$, with suggestions from teachers of Social Communication and Pedagogy. Characters and settings were created in CoreIDRAW ${ }^{\circ}$, from where the storyboard was extracted ${ }^{(8)}$.

At production stage, the educational video was constructed in the second dimension animation format (2D). Body movement and facial expressions of characters were performed with the GoAnimate program. The audio of the speech was recorded in a reserved place with adequate acoustics. In post-production, the edition used Final Cut Pro. The initial version of the video was converted into MP4 format.

For validation of content, an electronic form was created in Google Forms ${ }^{\circ}$, which was sent by e-mail. In it, the tool for validation of content was included, which assessed agreement and degree of relevance in 25 items. This tool, adapted from two validation studies of educational materials ${ }^{(6,13)}$, followed a specific assessment script ${ }^{(14)}$.

In the validation of appearance, it was made the invitation and delivery/sending of the documents to participants, the educational video was watched and the instrument of validation of appearance, adapted from two studies ${ }^{(6,13)}$, was filled out.

\section{Analysis of results and statistics}

The data were analyzed in the IBM ${ }^{\circ}$ SPSS ${ }^{\circ}$ Statistics software, version 20.0, describing the absolute frequencies. For validation of content, the Binomial Test was applied to the items of the tool, verifying the agreement ratio among judges, with an agreement index equal to or greater than $85 \%(P>0.85)$ and a $5 \%$ level of significance $(a)^{(13)}$. For relevance degree analysis of the items, Content Validity Index (CVI) was calculated by three mathematical equations, considering a content index validity $>0.80^{(7)}$. In the analysis of the understanding of the educational material by the other participants, the CVI was calculated for each item of the tool of validation of appearance.

\section{RESULTS}

In all focus groups, doubts and different levels of knowledge about HPV and vaccination were evidenced. The girls were unaware of the virus itself, linking it to cervical cancer and the vaccine, which also fights other cancers.

It is a ... breast cancer, skin cancer, cervical cancer vaccine (adolescents focus group).

About vaccines, there was the conception in all groups that it prevents cancer, but it was not seen among the mothers and their mothers that the protection is specific for cervical cancer, since it has been generalized with other diseases.

The girl grows protected. Prevents against cancer of the cervix and other diseases more, other than that there also. (parents focus group)

Resistance of girls and parents to HPV immunization has been reported by practitioners. It is noticed how the population is afraid of vaccination due to lack of knowledge about the subject.

Some people do not want to vaccinate in my area because they say it's bad. You will only get vaccinated after other girls get vaccinated and see that you did not give a problem. (CHA focus group)

To encourage vaccination, some actions were mentioned, such as publicity about campaigns, fairs, waiting rooms, shelters, home visits, schools and other social facilities, social networks, television and groups of adolescents. The trip to the health service with the youngest to administer the vaccine was also mentioned.

Educational materials, posters, pamphlets, comics, slides, games and puppet theater were suggested to talk about the vaccine, but the video was highlighted by the possibility of drawing more attention, as well as ease of viewing and sharing, based on successful previous experiences.

As in the unit we have the television in the waiting room and the $D V D$, video with us works. (higher education health professionals focus group)

Regarding the content that the material should address, questions and answers on the subject were recommended; stories/narratives involving vaccination; explanations about the female reproductive system, the virus, cervical cancer and the vaccine; vaccination; presence of an expert in the subject to provide explanations; myths and truths about immunization and consequences of non-vaccination.

The theoretical framework was composed of topics related to HPV, cervical cancer and vaccination against the virus. The audiovisual productions found in the researched collections were motivational and informative videos, with campaign messages and technical information about the vaccine, none of them offering the knowledge from real situations and constructed from the diagnosis made with the population. 
The script for the first version of the educational video resulted in a narrative consisting of seven characters and four scenes occurring at school, home and health unit. Conflicts about HPV vaccination in the daily routine of a traditional family and the decision-making of the parents for the immunization of their daughter based on knowledge acquired with an education professional and another about health were emphasized (Figure 1).

The storyboard was developed based on the first script, and presented six images, giving an idea of the physical characterization of characters, settings, colors, actions and emotions present in the video. Production and editing originated the first version called "It's time to protect yourself with the HPV vaccine", which lasts approximately 11 minutes.

In the validation of content, 19 judges belonged to higher education institutions in the Northeast and Southeast regions: 11 were specialists in women's health, seven specialists in public health or collective health and 17 had a doctorate. Besides these, three were from Northeastern care services, all with specialization in women's health and master's degree.

Agreement among judges for the assessed items was satisfactory in most of them, except for item 16, in which there was agreement/disagreement tie (11/11), and in item 17, in which 13 judges disagreed. $P$ value was $>0.05$ in 22 items, indicating the proportion of judges who agreed with the adequacy and relevance of the educational video (Table 1).

Relevance of the items expressed by the I-CVI (Item-Level Content Validity Index) separately, with the value of the S-CVI (ScaleLevel Content Validity Index) can be visualized in Table 1. I-CVI was $>0.80$ in most items assessed, except for items 5, 7, 13, 16 and 17. Relevance ratio (S-CVI/AVE, ScaleLevel Content Validity Index, Average Calculation Method) was equal to or above 0.80 for 17 judges.

The emitted suggestions led to modifications in items that had I-CVI below 0.80 . The opening became more dynamic and attractive, with questioning about the vaccine, inviting music, appropriate lyrics and beginning of the narrative in the classroom. To increase interest in the video, more action was

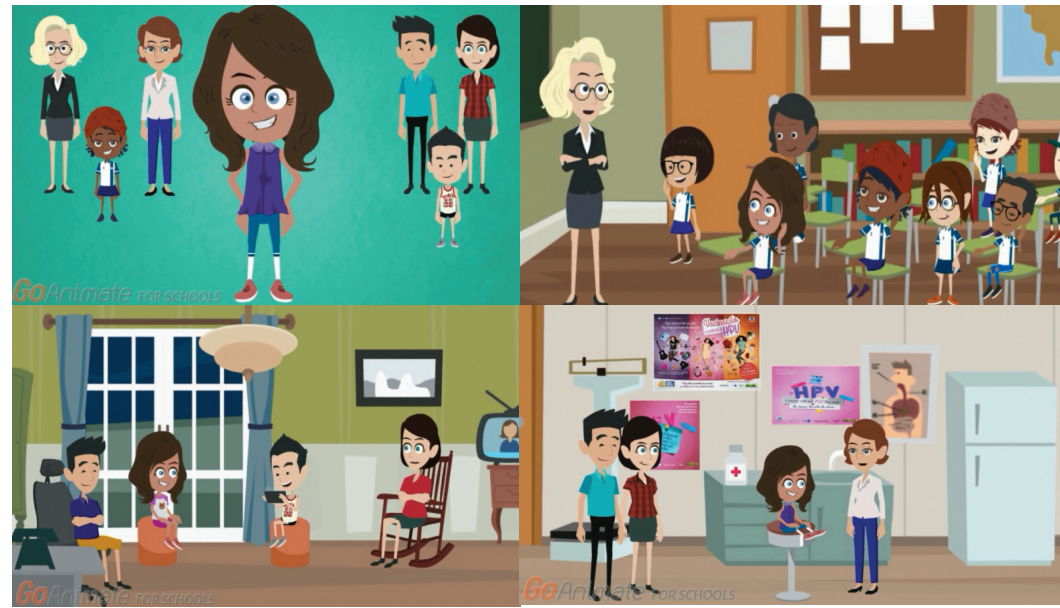

Note: HPV - human papillomavirus.

Figure 1 - Characters and scenes from educational video "It's time to protect yourself with the HPV vaccine"

Table 1 - Agreement and relevance of the items for validation of content of the educational video, according to judges, Recife, Pernambuco, Brazil, 2015 ( $N=22$ )

\begin{tabular}{|c|c|c|c|c|c|}
\hline \multirow{2}{*}{ Items assessed } & \multicolumn{2}{|c|}{ Agreement } & \multirow{2}{*}{$\boldsymbol{p}$} & \multirow{2}{*}{$p$} & \multirow{2}{*}{$\mathbf{I}-\mathbf{C V}$} \\
\hline & Yes & No & & & \\
\hline \multicolumn{6}{|l|}{ Concept of the idea } \\
\hline 1 Content promotes membership & 22 & 0 & 1.000 & 1.000 & 1.00 \\
\hline 2 Obvious goal & 22 & 0 & 1.000 & 1.000 & 1.00 \\
\hline 3 Contributions in knowledge and behavior change & 22 & 0 & 1.000 & 1.000 & 0.95 \\
\hline 4 Use by health professionals and education & 22 & 0 & 1.000 & 1.000 & 0.95 \\
\hline \multicolumn{6}{|l|}{ Dramatic construction } \\
\hline 5 Opening has impact & 12 & 10 & $<0.001$ & 0.545 & 0.72 \\
\hline 6 Conflict refers to real situations & 22 & 0 & 1.000 & 1.000 & 1.00 \\
\hline 7 Development of narrative increases interest & 18 & 4 & 0.424 & 0.818 & 0.77 \\
\hline 8 Decision-making is the climax & 21 & 1 & 0.972 & 0.954 & 1.00 \\
\hline 9 Outcome incentives vaccination & 21 & 1 & 0.972 & 0.954 & 0.90 \\
\hline \multicolumn{6}{|l|}{ Pace } \\
\hline 10 Number of scenes conveys the message & 19 & 3 & 0.661 & 0.863 & 0.95 \\
\hline 11 Satisfactory duration & 17 & 5 & 0.226 & 0.772 & 0.90 \\
\hline 12 Displaying a scene motivates to the next scene & 19 & 3 & 0.661 & 0.863 & 0.90 \\
\hline \multicolumn{6}{|l|}{ Characters } \\
\hline 13 Characters capture target audience, parents and teachers & 16 & 6 & 0.099 & 0.727 & 0.63 \\
\hline 14 Characters are representative & 20 & 2 & 0.863 & 0.909 & 0.95 \\
\hline 15 Interaction between characters conveys the message & 19 & 3 & 0.661 & 0.863 & 0.95 \\
\hline \multicolumn{6}{|l|}{ Dramatic potential } \\
\hline 16 Emotion in narrative & 11 & 11 & $<0.001$ & 0.500 & 0.45 \\
\hline 17 Humor in the speech of characters & 9 & 13 & $<0.001$ & 0.409 & 0.45 \\
\hline \multicolumn{6}{|l|}{ Dialogues } \\
\hline 18 Understandable and natural texts & 18 & 4 & 0.424 & 0.818 & 0.86 \\
\hline 19 Dialogues motivate to understand the theme & 20 & 2 & 0.863 & 0.909 & 0.81 \\
\hline 20 Active voice encourages habits that result in vaccination & 22 & 0 & 1.000 & 1.000 & 0.86 \\
\hline \multicolumn{6}{|l|}{ Visual style } \\
\hline 21 Appropriate illustrations & 19 & 3 & 0.661 & 0.863 & 0.81 \\
\hline 22 Illustrations convey content & 21 & 1 & 0.972 & 0.954 & 0.86 \\
\hline 23 Illustrations motivate the understanding of the message & 20 & 2 & 0.863 & 0.909 & 0.81 \\
\hline \multicolumn{6}{|l|}{ Referent audience } \\
\hline 24 Correspondence between content and the real world & 18 & 4 & 0.424 & 0.818 & 0.86 \\
\hline 25 Clear language & 22 & 0 & 1.000 & 1.000 & 0.95 \\
\hline $\mathrm{S}-\mathrm{CVI}$ & & & & & 0.85 \\
\hline
\end{tabular}

taken to events, movements and dialogues, so as not to make it monotonous. About characters, some audios were re-recorded with more expressiveness and motivation. To give more emotion, 
the speech became engaging and spontaneous, becoming more real. On the humor, the dialogs acquired a more adolescent performance, having interaction among students.

In the validation of appearance, the positive assessment of $100 \%$ of adolescents $(A)$ and mothers $(M)$ on the aspects related to the educational video revealed:

The opening of the video is interesting. I did not know, I learned more and more. (A1)

It gave more time to reflect on HPV. (A8)

Explain what happens if you do not take. (A4)

Holds the attention. Children is very fond of doll; it is interesting because they know what they are talking about. (M3)

It will be better for mothers who are afraid. (M8)

You could understand in a way that is not vulgar. (M7)

Most items obtained I-CVI equal to or above 0.80. Among teachers, items 4 and 5, regarding the length of the video and the ability of the scenes to convey the content, presented I-CVI of 0.70 each. Among video professionals, only item 4 had the I-CVI of 0.70 . S-CVI/AVE was greater than 0.80 for most participants. $\mathrm{S}-\mathrm{CVI}$ was above 0.80 for all groups.

To improve the video, the narrative time was shortened with the speech of characters processing at a faster pace, reducing pauses in movements, passage of scene and opening. To convey the message better, voices became even more spontaneous. In the classroom, blackboard showed information about vaccine and background colors were changed by the conventional setting, so as not to divert the viewer's attention.

The implementation of some suggestions emitted in the validation of the educational video resulted in a final version of the more dynamic material, with less duration and more details related to its content and the visual question.

\section{DISCUSSION}

The poorly detailed and confused knowledge about HPV and the vaccine against the virus, evidenced in the focus groups for the construction of educational technology, may be related to the immunobiological being a new method of cancer prevention offered by the MoH in Brazil, from 2014. Previously, it was little publicized, although production began in 2006. Since the implantation, doubts have arisen about its effectiveness and safety ${ }^{(15)}$. Thus, the video constructed sought to address issues that meet the demands of the groups, translating into a dynamic resource for dissemination of knowledge.

The diagnosis of HPV and vaccination in focus groups allowed identifying what is known about the topic, the gaps, information needs and video as educational technology. This has given a differential to the material, which will lead to the knowledge about the vaccine that is based on the reality of the population and which can provoke reflections for behavior changes, favoring vaccination. In a similar way, a survey was carried out with chaperones about the knowledge in the subject in the elaboration phase of an educational manual ${ }^{(16)}$. However, other ways can be followed in the construction of an educational video, based on research on the subject ${ }^{(17)}$.

The video was the technology chosen, in this study, to be attractive, easily accessible and for contributing to the learning in educational actions in the community. Their employability could promote satisfactory outcomes by increasing vaccine indices and preserving women's health. It is expected that its effect will be similar to that provoked by a video on the knowledge about the postoperative care of children with cleft lip and palate, with favorable results for the intervention group, proving the efficacy of this material in experimental studies ${ }^{(18)}$.

According to the World Health Organization, two doses of the HPV vaccine are sufficient to protect against cervical cancer ${ }^{(19)}$. Thus, the educational video elaborated sought to meet this recommendation and respond to the concerns generated in focus groups. Conflicts related to resistance to immunization were also addressed, aiming to demystify conceptions that prevent the protection. The reasons cited in literature for non-vaccination are: no risk of contracting a sexually transmitted infection, need for more information about the vaccine, immunobiological being new, decision to immunize the child and lack of medical indication ${ }^{(20)}$.

The development of the educational video of this study was based on a theoretical reference that determines that the production process is organized from three stages ${ }^{(8)}$. This foundation gave higher quality to the material, directing the steps to its composition. In accordance with this procedure, a video on chemotherapy treatment as an education strategy for cancer patients used a theoretical framework that specified the phases necessary for its elaboration: analysis and planning, modeling, implementation, assessment and maintenance and distribution ${ }^{(21)}$.

Validation of content provided scientific recognition that was associated with educational video. In it, all judges agreed that its content promotes adherence to vaccination, considering it suitable for use. Text comprehension and coherence of illustrations also obtained satisfactory scores, indicating that the information used is appropriate. The items related to these domains had a value of $p>0.05$ and $\mathrm{I}-\mathrm{CVI}>0.80$, proving that the use of the educational tool in practice is acceptable. A video on central venous catheter dressing also had the items properly assessed in the validation process, mainly regarding content and images, being considered apt to be available and useful in professional nursing training ${ }^{(22)}$.

Changes are common in the validation of educational materials. In this study, the value of S-CVI for video was 0.85 , but the five items that presented $\mathrm{I}-\mathrm{CVI}<0.80$ in validation of content were modified based on the suggestions made by the experts, making them more enriched and clearer. In the first scene, the proposal was of a livelier opening to awaken the attention of the viewer in its visualization, from the use of more attractive sounds and images, mainly by the younger age groups. Similarly, in the introduction of an educational video on oral hygiene of patients undergoing chemotherapy, changes were also suggested, all of which were adhered to and the modified script ${ }^{(23)}$.

The use of technologies that promote adherence to HPV vaccination is advocated by $\mathrm{MoH}$ in an attempt to focus efforts to guide the population on cervical cancer prevention ${ }^{(24)}$. In order to comply with this recommendation, the elaborated video is a 
strategy to disseminate knowledge about the subject, and may lead to the adoption of behaviors that result in immunization from the involvement of those who watch it. For this, the interest in the narrative increased with agility to the actions and the speeches that resemble the adolescent language, approaching its cultural environment. Thus, it can be used in educational actions, conquering the target audience and parents for immunization.

Video can be used in an interactive environment such as school, in order to enhance expression and communication, proposing a pedagogical action that generates learning ${ }^{(25)}$. Therefore, characters became more involved to captivate the target audience of the educational video, since the development of health themes in the school environment with the help of this tool, with the student community and the family, requires notable figures who are approaching and generate motivation. These adjustments, made in the production of the material, provided their adequacy to the proposed objective. Otherwise, there could be public disinterest and low video effectiveness at school and at other educational places.

Emotion and humor were best explored in the video to disclose the information of vaccination through entertainment in order to draw attention in an inviting, fun and gentle way. Communication force of images represents a superposition of sensory, visual, spoken, musical and written languages, reaching the senses, which facilitates the use of audiovisual in health education. It has the power to seduce, inform, entertain, transport to the imaginary, to other times and spaces ${ }^{(26)}$. Considering these considerations, the final version of the constructed video invested in images and sounds that sensitized to the vaccination, able to reproduce different sensations in its exhibition.

The validation of appearance verified the understanding of the items by the members of the population to which the educational video is destined. The inclusion of these participants contributed to material appropriateness, which will be used by others later, turning it into a more attractive, relevant, appropriate resource and that arouses greater interest of those who attend, from the implemented adjustments. With this same purpose, an educational video for teaching deaf students about cardiopulmonary resuscitation involved the participation of the target audience in their assessment ${ }^{(27)}$.

The insertion of video professionals in the validation of appearance gave more technical quality to the final version of the educational tool. This judgment raised some details previously unobserved and brought about coherent changes in its production and editing, collaborating to make it even more enriched. Likewise, qualified professionals were included in the technical assessment of an educational video for the prevention of childhood diarrhea ${ }^{(6)}$.

The version of the educational technology submitted to the validation of appearance had duration that framed it like video of social intervention, those that approach of 15 to 20 minutes $^{(28)}$. The audiovisual was assessed as long, so it was decided to leave it with a duration of close to ten minutes, without there being any cuts in the contents, so as not to de-characterize it. In this question, it was considered that a very short video would make it impossible to convey knowledge deemed essential to achieve the proposed objective.

The relevance of the educational video was asserted by most participants in the validation of appearance as to the clarity of the scenes. The small adjustments, after this step, facilitated the transmission of the message, making it more. A similar situation was seen in the assessment of a short video to promote pneumococcus vaccination, in which the target public expressed positive reactions to their understanding and raised suggestions for their improvement ${ }^{(29)}$.

\section{Study limitations}

The educational video, constructed and validated in this study, was based on vaccination protocols made available by the SUS, with current information on HPV vaccine at the time of its elaboration and subsequent years. Therefore, its application in other countries may be limited, needing to adapt to the reality of certain places.

\section{Contributions to Nursing, Health or Public Policy}

The final version of the educational video will support educational actions aimed at girls, boys and parents in schools and health services about HPV immunization. As it is an educational technology, it will enable the facilitators of these activities to innovate ways to exchange knowledge with the public, favoring the construction and reconstruction of knowledge, instrumentalizing learning and contributing to the advancement of education. In addition, video is an educational material option for health education actions offered to the general population.

Guidelines on HPV vaccination should be part of the care provided by health professionals, including nurses, and educational activities at school. For this, an educational video about the subject, built under several eyes, can serve as a communication vehicle and cooperate in the improvement of vaccination rates.

\section{CONCLUSIONS}

The educational video with an emphasis on adherence to HPV vaccination, prepared with the participation of several actors involved in the subject, was validated as to the content among judges, and in appearance, with representatives of their target audience, educators and experienced professionals in audiovisuals.

However, it is important to note that new studies should be developed with the constructed material, such as randomized clinical trials, to verify its effectiveness in relation to immunization against the virus.

\section{REFERENCES}

1. Ministério da Saúde. (BR). Secretaria de Vigilância em Saúde. Informe técnico da ampliação da oferta das vacinas papilomavírus humano 6 , 11, 16 e 18 (recombinante) - vacina HPV quadrivalente e meningocócica C (conjugada) [Internet]. Brasília: Ministério da Saúde; 2018 [cited 2019 Mar 18]. 39 p. Available from: http://portalarquivos2.saude.gov.br/images/pdf/2018/marco/14/Informe-T--cnico-HPV-MENINGITE.pdf 
2. Zouheir Y, Daouam S, Hamdi S, Alaoui A, Fechtali T. Knowledge of Human Papillomavirus and Aceptability to Vaccinate in adolescents and young adults of Moroccan population. J Pediatr Adolesc Gynecol. 2015:1-11. doi: 10.1016/j.jpag.2015.11.002

3. Unger Z, Maitra A, Kohn J, Devaskar S, Stern L, Patel A. Knowledge of HPV among Women Ages 19 to 26. Women's Health Issues. 2015;25(5):458-62. doi: 10.1016/j.whi.2015.06.003

4. Santos JGS, Dias JMG. Vacinação pública contra o papilomavirus humano no Brasil. Rev Med Minas Gerais. 2018;28:e-1958. doi: $10.5935 / 2238-3182.20180048$

5. Silveira BJ, Moro VCD, Silveira MB, Espírito-Santo LR, Prince KA. Adesão à imunização na saúde pública do Brasil. Espaço para a saúde Revista de Saúde Pública do Paraná. 2017;18(1):157-64. doi: 10.22421/1517-7130.2017v18n1p157

6. Nascimento LA, Rodrigues AP, Joventino ES, Vieira NFC, Pinheiro PNC, Ximenes LB. Validation of Educational Video to Promote Self-Efficacy in Preventing Childhood Diarrhea. Health. 2015;7(2):192-200. doi: 10.4236/health.2015.72022

7. Polit DF, Beck CT. Fundamentos de pesquisa em enfermagem: avaliação de evidências para a prática da enfermagem. 9. ed. Porto Alegre: Artmed; $2019.431 \mathrm{p}$.

8. Kindem G, Musburger RB. Introduction to media production: The path to digital media production. 4th. ed. Boston: Focal Press; 2009. 532 p.

9. Pasquali L. Instrumentação psicológica: fundamentos e práticas. Porto Alegre: Artmed; 2010. 560 p.

10. Trad LAB. Grupos focais: conceitos, procedimentos e reflexões baseadas em experiências com o uso da técnica em pesquisas em saúde. Physis. 2009;19(3):777-96. doi: 10.1590/S0103-73312009000300013

11. Lopes MVO, Silva VM, Araújo TL. Validação de diagnósticos de enfermagem: desafios e alternativas. Rev Bras Enferm. 2013;66(5):649-55. doi: 10.1590/S0034-71672013000500002

12. Fehring R. Methods to validate nursing diagnoses. Heart Lung [Internet]. 1987 [cited 2019 Mar 18];16(6):625-9. Available from: https://pdfs. semanticscholar.org/11f7/d8b02e02681433695c9e1724bd66c4d98636.pdf

13. Oliveira SC, Lopes MVO, Fernandes AFC. Development and validation of an educational blooket for health eating during pregnancy. Rev Latino-Am Enfermagem. 2014;22(4):611-20. doi: 10.1590/0104-1169.3313.2459

14. Comparato D. Da criação ao roteiro: teoria e prática. São Paulo: Summus; $2009.494 \mathrm{p}$

15. Nunes CBL, Arruda KM, Pereira TN. Apresentação da eficácia da vacina HPV distribuída pelo SUS a partir de 2014 com base nos estudos Future I, Future II, e Villa et al. Acta Biomédica Brasiliensia [Internet]. 2015 [cited 2019 Mar 18];6(1):1-9. Available from: http://www. actabiomedica.com.br/index.php/acta/article/view/106/79

16. Teles LMR, Oliveira AS, Campos FC, Lima TM, Costa CC, Gomes LFS, et al. Development and validating an educational booklet for childbirth companions. Rev Esc Enferm USP. 2014;48(6):977-84. doi: 10.1590/S0080.623420140000700003

17. Silva NF, Silva NCM, Ribeiro VS, lunes DH, Carvalho EC. Construction and validation of an educational video on foot reflexology. Rev Eletr Enf. 2017;19:a48. doi: 10.5216/ree.v19.44324

18. Razera APR, Trettene AS, Mondini CCSD, Cintra FMRN, Tabaquim MLM. Educational video: a training strategy for caregivers of children with cleft lip and palate. Acta Paul Enferm. 2016;29(4):430-38. doi: 10.1590/1982-0194201600059

19. World Health Organization. Human papillomavirus vaccine: WHO position paper, October 2014: recommendations. Vaccine. 2015;33(36):4383-4. doi: 10.1016/j.vaccine.2014.12.002

20. Osis MJD, Duarte GA, Sousa MH. SUS users' knowledge of and vaccines available in Brazil. Rev Saúde Pública. 2014;48(1):123-33. doi: 10.1590/S0034-8910.2014048005026

21. Razera APR, Buetto LS, Lenza NFB, Sonobe HM. Video educational: teaching-learning strategy for patients chemoterapy treatment. Cienc Cuid Saúde. 2014;13(1):173-8. doi: 10.4025/cienccuidsaude.v13i1.19659

22. Ferreira MVF, Godoy S, Góes FSN, Rossini FP, Andrade D. Lights, camera and action in the implementation of central venous catheter dressing. Rev Latino-Am Enfermagem. 2015;23(6):1181-6. doi: 10.1590/0104-1169.0711.2664

23. Braga FTMM, Garbin LM, Marmol MT, Khouri VY, Vasques Cl, Carvalho EC. Oral hygiene in chemoterapy patients: construction and validation of an educational video. Rev Enferm UFPE. 2014;8(10):3331-9. doi: 10.5205/1981-8963-v8i10a10064p3331-3339-2014

24. Silva PMC, Silva IMB, Interaminense INCS, Linhares FMP, Serrano SQ, Pontes CM. Knowledge and attitudes about human papillomavirus and vaccination. Esc Anna Nery. 2018;22(2):1-7. doi: 10.1590/2177-9465-ean-2017-0390

25. Costa SRS, Duqueviz BC, Pedroza RLS. Tecnologias digitais como instrumentos mediadores da aprendizagem dos nativos digitais. Psicol Esc Educ. 2015;19(3):603-10. doi: 10.1590/2175-3539/2015/0193912

26. Bahia AB, Silva ARL. Modelo de produção de vídeo didático para EaD. Revista Paidéi@ [Internet]. 2017 [cited 2019 May 6];9(16):1-23. Available from: http://periodicos.unimesvirtual.com.br/index.php/paideia/article/view/696/665

27. Galindo-Neto NM, Alexandre ACS, Barros LM, Sá GGM, Carvalho KM, Caetano JA. Creation and validation of an educational video for deaf people about cardiopulmonary resuscitation. Rev Latino-Am Enfermagem. 2019;27:e3130. doi: 10.1590/1518-8345.2765.3130

28. Moraes AF. A diversidade cultural presente nos vídeos em saúde. Interface. 2008;12(27):811-22. doi: 10.1590/S1414-32832008000400011

29. Brown T, Goldman SN, Persell SD, Lee JY, Doan CT, Stephens Q, et al. Development and evaluation of a patient education video promoting pneumococcal vaccination. Patient Educ Couns. 2017;100(5):1024-27. doi: 10.1016/j.pec.2016.12.025 